\title{
Civilidade, distinção e identidade nacional nas páginas do Cozinheiro Imperial (1840)
}

\section{Civility, distinction, and national identity in the pages of the cookbook Cozinheiro Imperial (1840)}

Patrícia Maria da Silva Merlo ${ }^{1}$

A chegada da Corte lusa ao Rio de Janeiro, em 1808, reforçou a importância da alimentação como critério de diferenciação social. Saber comportar-se em público, sobretudo à mesa, era essencial para os membros da elite local por expressar sua conformidade cultural e social com os pares portugueses. Aliás, tal forma de comportamento, replicada dos modelos de comportamento das cortes europeias, converteu-se em um dos meios que as elites açucareira e cafeicultora encontraram para sustentar sua distinção social, nos termos de Pierre Bourdieu. No decurso do século XIX, o Rio de Janeiro, capital do país, corte da monarquia e maior porto comercial, converteu-se no modelo de comportamento que deveria moldar o novo país. Contudo, mesmo após a independência, a elite local continuou a se europeizar, assinalando mais profundamente a distinção entre os vários grupos que compunham a sociedade brasileira.

O primeiro receituário nacional nasceu nesse cenário, Cozinheiro Imperial, publicado em 1840. Sua principal base foram os livros portugueses Arte de Cozinha, de autoria de Domingos Rodrigues, publicado em 1680, e Cozinheiro Moderno, de Lucas Rigaud, datado de 1780. Soma-se a isso a influência francesa, em menor medida. Todavia, diferentemente de Portugal, no Brasil ainda se estava vivenciando a fixação de um discurso sobre a alimentação, tanto nas relações com a prática culinária, quanto com seu aspecto discursivo. Por isso, muitas novidades ligadas à emergência da gastronomia enquanto campo autônomo aparecem de maneira pálida em Cozinheiro Imperial. De fato, o primeiro livro de cozinha brasileiro não atesta uma "culinária brasileira", mas suas reedições parecem apontar que a ampliação do público leitor implicou na reinterpretação e inclusão de ingredientes e modos de preparo mais ao gosto local. Acreditamos que o uso crescente de ingredientes locais e de receitas à brasileira pode ser interpretado como indício do lento delineamento da cozinha nacional, que caracterizou a emergência das cozinhas regionais no final do século XIX. Como apontado por Carlos Dória, o Cozinheiro Imperial representou o esforço inicial de nacionalização do saber culinário e, por essa razão, foi um marco na formação do pensamento brasileiro sobre o comer entre a elite agrária e os setores urbanos do país. No entanto, esse esforço esteve associado ao que a elite quis comer como construção de nacionalidade, preservando-se, pari passu, fiel ao modo de vida europeizado. Não obstante, Cozinheiro Imperial, apesar de reunir receitas aos moldes internacionais, já integrava na sua apresentação o apelo para que o livro fosse abrasileirado. Assim como o Instituto Histórico e Ceográfico Brasileiro começava a escrever uma história do Brasil, o receituário colaborou para o fortalecimento dessa identidade nacional em construção.

Palavras-chave: Cozinheiro Imperial; história da alimentação; civilidade; identidade nacional; receituário. Keywords: Cozinheiro Imperial; food history; civility; national identity; recipes. 